\title{
Scribal Abbreviations
}

ACW William Godwin, Adventures of Caleb Williams

$B A \quad$ A Society of Gentlemen, The British Apollo

$B B \quad$ George Colman the younger, Blue-beard

CGJ Henry Fielding, The Covent Garden Journal

EHU David Hume, Enquiry Concerning Human Understanding

FC George Lillo, Fatal Curiosity

FS Eliza Haywood, The Female Spectator

GT Jonathan Swift, Gulliver's Travels

HR Samuel Johnson, The History of Rasselas, Prince of Abissinia

IDL, ADV Samuel Johnson, The Idler and The Adventurer

KJV Bible, King James Version

LT Blake Crouch, The Last Town

MU Ann Radcliffe, The Mysteries of Udolpho

NA Jane Austen, Northanger Abbey

$P \quad$ Blake Crouch, Pines

$P L \quad$ John Milton, Paradise Lost

RAM Samuel Johnson, The Rambler

RF Ann Radcliffe, The Romance of the Forest

RL Alexander Pope, The Rape of the Lock

SPEC Joseph Addison and Richard Steele, The Spectator

TAT Joseph Addison and Richard Steele, The Tatler

THN David Hume, Treatise of Human Nature

TI Ann Radcliffe, The Italian

TIC George Colman the younger, The Iron Chest

TMW Francis Bacon, The Major Works

$V \quad$ William Beckford, Vathek

WB Thomas Browne, The Works of Sir Thomas Browne 
